\title{
Intangible Assets of Irrigation System in East Java, Indonesia
}

\section{Nugroho Tri Waskitho*, Jabal Tarik Ibrahim, Dyah Erny Widyastuti}

\author{
Faculty of Agriculture and Animal Husbandry, University of Muhammadiyah Malang, Indonesia
}

*Corresponding Author: Nugroho Tri Waskitho, Faculty of Agriculture and Animal Husbandry, University of Muhammadiyah Malang, Indonesia.

Received: July 29, 2019; Published: August 20, 2019

DOI: 10.31080/ASAG.2019.03.0626

\begin{abstract}
Irrigation system management in Indonesia has prioritized infrastructure aspects (tangible assets), while intangible aspects such as human resources, institutional and management receive less attention. This situation causes intangible assets in the irrigation system in Indonesia is still weak so that the performance of the system is not as expected. The study was conducted in May - July in 2018 in the Water Resources Division of the Public Works and Spatial Planning Office of Jombang Regency, the Water Resources Division of the Public Works and Spatial Planning Office of Lumajang Regency, and the Public Works Water Resources Office of Malang Regency, East Java, Indonesia. Data collection was using a questionnaire. Data analysis was using quantitative descriptive. The results showed that (i) intangible assets consisting of moral intelligence, emotional intelligence, creative attitudes and institutional culture were in good categories, (ii) knowledge management as controlling the intangible assets were also in good category.
\end{abstract}

Keywords: Intangible Assets; Evaluation; Irrigation System

\section{Introduction}

The agricultural sector has a very strategic role in national development in Indonesia. The agriculture, forestry and fisheries sector in 2015 contributed IDR 1,174.5 trillion to GDP. The situation is in third place after the manufacturing and trade industry sector [1]. Irrigation is a key component in the agricultural sector. Irrigation is able to increase agricultural yields from 100 to $200 \%$ [2]. Irrigation land plays a significant role in the procurement of food production until now $85 \%$ of national rice production is produced in paddy fields with an area of 4.65 million ha [3]. Irrigation is a very important aspect of agricultural development in Indonesia.

Irrigation is a socio-cultural system of society so that it is dynamic depending on the environmental conditions [4]. In the current information age these environmental conditions are undergoing rapid changes due to the rapid development of information technology, globalization and democratization [5]. Social and political reform in 1998 has led to a paradigm shift in the irrigation sector [6]. The reform demanded that irrigation management be carried out in a transparent, accountable and fair manner. To realize this intangible asset is a very important factor. Intangible assets affect organizational management processes $[7,8]$, and affect corporate performance [9-12].
Irrigation system management in Indonesia has prioritized infrastructure aspects (tangible assets), while intangible aspects such as human, institutional and management receive less attention. This situation causes intangible assets in the irrigation system in Indonesia is still weak so that the performance of the system is not as expected. Irrigation water management by irrigation officers is not good so irrigation water services have not been optimal. The concept of centralistic operation and maintenance of irrigation in Indonesia causes the sense of belonging to farmers to the irrigation network to decline. This causes a loss of irrigation culture in the farming community so that the irrigation system is less efficient and the network damage is higher [13]. Farmer participation in tertiary level irrigation system management has experienced annual shrinkage of 0.045 in the Molecular Irrigation System, 0.033 in the Sapon Irrigation System, and 0.041 in the Mejing Irrigation System for the period 1998-2008 [14]. Such conditions will reduce the performance of the irrigation system. Knowledge management can control intangible assets in tertiary level irrigation system management [15]. The knowledge management model can also control intangible assets in secondary level irrigation system management [16]. 


\section{Method}

The study was conducted in May - July in 2018 in the Department of Water Resources of the Public Works and Spatial Planning Office of Jombang Regency, the Water Resources Division of the Public Works and Spatial Planning Office of Lumajang Regency, and the Public Works Water Resources Office of Malang Regency, East Java, Indonesia. The variables studied are intangible assets consisting of moral intelligence, emotional intelligence, creative attitudes, institutional culture and knowledge management. Respondents were employees of the Water Resources Division of the Public Works and Spatial Planning Office of Jombang Regency, the Water Resources Division of the Public Works and Spatial Planning Office of Lumajang Regency, and the Public Works Water Resources Office of Malang Regency, East Java, Indonesia. Data collection using a questionnaire. Data analysis uses quantitative descriptive.
Results and Discussion

Intangible assets of irrigation system in east java

Intangible assets of the irrigation system in East Java represented by employees of the Water Resources Division of the Public Works and Spatial Planning Office of Jombang Regency, the Water Resources Division of the Public Works and Spatial Planning Office of Lumajang Regency, and the Public Works Water Resources Office of Malang Regency, East Java, Indonesia consisting of moral intelligence, emotional intelligence, creative attitudes and institutional culture are presented in table 1, 2 and 3.

Table 1 shows that most employees (80.8\%) have good moral intelligence. Employees have a good willingness to integrate universal values in their behavior, are responsible for their actions and understand their consequences, try not to harm others, and be compassionate.

\begin{tabular}{|l|c|c|c|c|c|c|c|c|}
\hline \multirow{2}{*}{ Category } & \multicolumn{2}{|c|}{ Moral intelligence } & \multicolumn{2}{c|}{ Emotional intelligence } & \multicolumn{2}{c|}{ Creative attitude } & \multicolumn{2}{c|}{ Institutional culture } \\
\cline { 2 - 9 } & Amount & $\mathbf{( \% )}$ & Amount & $\mathbf{( \% )}$ & Amount & $\mathbf{( \% )}$ & Amount & (\%) \\
\hline Very Poor & 0 & 0,0 & 0 & 0,0 & 0 & 0,0 & 0 & 0,0 \\
\hline Poor & 0 & 0,0 & 1 & 3,8 & 2 & 7,7 & 0 & 0,0 \\
\hline Moderate & 2 & 7,7 & 7 & 26,9 & 8 & 30,8 & 3 & 11,5 \\
\hline Good & 21 & 80,8 & 16 & 61,5 & 14 & 53,8 & 18 & 69,2 \\
\hline Very Good & 3 & 11,5 & 2 & 7,7 & 2 & 7,7 & 5 & 19,2 \\
\hline Amount & 26 & 100,0 & 26 & 100,0 & 26 & 100,0 & 26 & 100,0 \\
\hline
\end{tabular}

Table 1: Intangible Assets of Irrigation System in Jombang Regency.

Most employees (61.5\%) have emotional intelligence in the good category. Most employees have a good ability to understand their emotions accurately and accurately in a variety of situations consistently, managing emotions well, striving to achieve goals with enough enthusiasm, strong passion and self-confidence and positive thinking about something, understand the emotions of others from their actions that appear and interact positively with others.

Most employees (53.8\%) have a creative attitude in the good category. Most employees have good ability in using ideas to solve a problem, in finding various ideas for solving problems outside of the usual categories, in providing unique or extraordinary responses, and in expressing detailed ideas to make them happen reality.
Most employees (69.2\%) have good institutional culture. The behavior of employees of the irrigation system of Molek secondary level is in line with the objectives of the institution, decisions are taken by consensus, thinking in order to achieve common goals, feeling of having an institution, having a family relationship, the welfare of farmers being a priority farmers have the spirit of learning continuously towards progress, giving awards to employees who excel and make decisions based on empirical data.

Table 2 shows that most employees (78.6\%) have good moral intelligence. Employees have a good willingness to integrate universal values in their behavior, are responsible for their actions and understand their consequences, try not to harm others, and be compassionate.

\begin{tabular}{|l|c|c|c|c|c|c|c|c|}
\hline \multirow{2}{*}{ Category } & \multicolumn{2}{|c|}{ Moral intelligence } & \multicolumn{2}{c|}{ Emotional intelligence } & \multicolumn{2}{c|}{ Creative attitude } & \multicolumn{2}{c|}{ Institutional culture } \\
\cline { 2 - 9 } & Amount & $\mathbf{( \% )}$ & Amount & $\mathbf{( \% )}$ & Amount & $\mathbf{( \% )}$ & Amount & $\mathbf{( \% )}$ \\
\hline Very Poor & 0 & 0,0 & 0 & 0,0 & 0 & 0,0 & 0 & 0,0 \\
\hline Poor & 0 & 0,0 & 3 & 21,4 & 0 & 0,0 & 0 & 0,0 \\
\hline Moderate & 0 & 0,0 & 0 & 0,0 & 5 & 35,7 & 8 & 57,1 \\
\hline Good & 11 & 78,6 & 9 & 64,3 & 5 & 35,7 & 5 & 35,7 \\
\hline Very Good & 3 & 21,4 & 2 & 14,3 & 2 & 14,3 & 1 & 7,1 \\
\hline Amount & 14 & 100,0 & 14 & 100,0 & 14 & 100,0 & 14 & 100,0 \\
\hline
\end{tabular}

Table 2: Intangible Assets of Irrigation System in Lumajang Regency. 
Most employees (64.3\%) have emotional intelligence in the good category. Most employees have a good ability to understand their emotions accurately and accurately in a variety of situations consistently, managing emotions well, striving to achieve goals with enough enthusiasm, strong passion and self-confidence and positive thinking about something, understand the emotions of others from their actions that appear and interact positively with others.

Most employees (35.7\%) have a creative attitude in the good category. Most employees have good ability in using ideas to solve a problem, in finding various ideas for solving problems outside of the usual categories, in providing unique or extraordinary responses, and in expressing detailed ideas to make them happen reality.

Most employees (57.1\%) have good institutional culture. The behavior of employees of the irrigation system of Molek secondary level is in line with the objectives of the institution, decisions are taken by consensus, thinking in order to achieve common goals, feeling of having an institution, having a family relationship, the welfare of farmers being a priority farmers have the spirit of learning continuously towards progress, giving awards to employees who excel and make decisions based on empirical data.

Table 3 shows that most employees ( $82.8 \%$ ) have good moral intelligence. Employees have a good willingness to integrate universal values in their behavior, are responsible for their actions and understand their consequences, try not to harm others, and be compassionate.
Most employees (65.5\%) have emotional intelligence in the good category. Most employees have a good ability to understand their emotions accurately and accurately in a variety of situations consistently, managing emotions well, striving to achieve goals with enough enthusiasm, strong passion and self-confidence and positive thinking about something, understand the emotions of others from their actions that appear and interact positively with others.

Most employees (65.5\%) have a creative attitude in the good category. Most employees have good ability in using ideas to solve a problem, in finding various ideas for solving problems outside of the usual categories, in providing unique or extraordinary responses, and in expressing detailed ideas to make them happen reality.

Most employees (72.4\%) have good institutional culture. The behavior of employees of the irrigation system of Molek secondary level is in line with the objectives of the institution, decisions are taken by consensus, thinking in order to achieve common goals, feeling of having an institution, having a family relationship, the welfare of farmers being a priority farmers have the spirit of learning continuously towards progress, giving awards to employees who excel and make decisions based on empirical data.

\section{Knowledge management in east java}

Knowledge Management in east Java irrigation system presented in table 4.

\begin{tabular}{|l|c|c|c|c|c|c|c|c|}
\hline \multirow{2}{*}{ Category } & \multicolumn{2}{|c|}{ Moral intelligence } & \multicolumn{2}{c|}{ Emotional intelligence } & \multicolumn{2}{c|}{ Creative attitude } & \multicolumn{2}{c|}{ Institutional culture } \\
\cline { 2 - 10 } & Amount & $\mathbf{( \% )}$ & Amount & $\mathbf{( \% )}$ & Amount & (\%) & Amount & (\%) \\
\hline Very Poor & 0 & 0,0 & 0 & 0,0 & 0 & 0,0 & 0 & 0,0 \\
\hline Poor & 0 & 0,0 & 1 & 3,84 & 0 & 0,0 & 1 & 3,4 \\
\hline Moderate & 1 & 3,4 & 6 & 20,7 & 3 & 10,3 & 6 & 20,7 \\
\hline Good & 24 & 82,8 & 19 & 65,5 & 19 & 65,5 & 21 & 72,4 \\
\hline Very Good & 4 & 13,8 & 4 & 7,7 & 7 & 6,8 & 1 & 3,4 \\
\hline Amount & 29 & 100,0 & 29 & 100,0 & 29 & 100,0 & 29 & 100,0 \\
\hline
\end{tabular}

Table 3: Intangible Assets of Irrigation System in Malang Regency.

\begin{tabular}{|l|c|c|c|c|c|c|c|c|}
\hline \multirow{2}{*}{ Category } & \multicolumn{2}{|c|}{ Jombang Regency } & \multicolumn{2}{c|}{ Lumajang Regency } & \multicolumn{2}{c|}{ Malang Regency } & \multicolumn{2}{c|}{ Average } \\
\cline { 2 - 10 } & Amount & $\mathbf{( \% )}$ & Amount & $\mathbf{( \% )}$ & Amount & (\%) & Amount & (\%) \\
\hline Very Poor & 0 & 0,0 & 0 & 0,0 & 0 & 0,0 & 0,0 & 0,0 \\
\hline Poor & 0 & 0,0 & 0 & 0,0 & 0 & 0,0 & 0,0 & 0,0 \\
\hline Moderate & 4 & 15,4 & 0 & 0,0 & 0 & 0,0 & 1,3 & 5,1 \\
\hline Good & 18 & 69,2 & 11 & 78,6 & 19 & 65,5 & 16,0 & 71,1 \\
\hline Very Good & 4 & 15,4 & 3 & 21,4 & 10 & 34,5 & 5,7 & 23,8 \\
\hline Amount & 26 & 100,0 & 14 & 100,0 & 29 & 100,0 & 23 & 100,0 \\
\hline
\end{tabular}

Table 4: Knowledge Management in east Java irrigation system. 
Table 4 shows that most irrigation system managers in East Java $(71.1 \%)$ have good knowledge management. This implies that they have an adult person, share vision, system thinking, mental models and very poor team learning. Most employees have a good level of organizational principles. They have the formulation of clear objectives, division of labor and delegation of power, range of power, levels of supervision, unity of orders and responsibility and good coordination. Most employees have a good level of organizational policy and strategy. They have unified and integrated formulations and plans that link organizational excellence with environmental challenges, which are designed to ensure that the main objectives of the organization can be achieved through the proper implementation of the organization. Most employees have a good level of information and communication technology. They have good understanding and use of information and communication technology.

\section{Conclusion}

The results showed that (i) intangible assets of Irrigation System in East Java, Indonesia consisting of moral intelligence, emotional intelligence, creative attitudes and institutional culture were in good categories, and (ii) knowledge management was also in good category.

\section{Acknowledgments}

Thank you to the Water Resources Division of the Office of Public Works and Environmental Management of Jombang Regency, the Water Resources Division of the Public Works and Spatial Planning Office of Lumajang Regency, and the Public Works Water Resources Office of Malang Regency for being willing to be a place of research and the Director of Research and Development of the Ministry of Research, Technology and Higher Education who have funded this research.

\section{Bibliography}

1. Central Statistics Bureau. Official Statistics News (2016).

2. Kurnia U. "Prospek Pengairan Pertanian Tanaman Semusim Lahan Kering”. Jurnal Litbang Pertanian 23 (2004).

3. Pasandaran EP., et al. "Prespective of Rice Production in Indonesia”. Dalam Sumarno, Suparyono, A.M. Faqi dan M.O. Adnyana (Eds) Rice Industry, Culture, and Environment, Book I. Indonesia Center for Rice Research (2006).

4. Pusposutardjo S. "Persoalan dan Penyelesaian Manajemen Irigasi Yang Berkeadilan”. Makalah Seminar Sistem Subak di Bali Menghadapi Era Globalisasi, Denpasar (2004).

5. Garvin D. "Learning in Action: A Guide to Putting the Learning Organizaton to Work". Harvad Business School Press (2000).

6. Arif SS. “Operasi dan Pemeliharaan (O\&P) Irigasi Masa Depan: Sebuah Gagasan dan Upaya Menghadapi Tantangan". Makalah diskusi dengan Dinas Sumberdaya Air Kabupaten Banyumas, Purwokerto (2005).
7. Stewart TA. "Intellectual Capital". Doubleday Dell Publishing Group, Inc. New York (1999).

8. Engstrom TEJ., et al. "Evaluating Intellectual Capital in the Hotel Industry”. Journal of Intellectual Capital 4 (2005): 287-303.

9. Bontis N. "Intellectual Capital: An Exploratory Study that develops measure and model". Management Decision 36.2 (1998): 63-76.

10. Bontis N., et al. "Intellectual Capital and Business Performance in Malaysian Industries". Journal of Intellectual Capital 1.1 (2000): 85-100.

11. Cabrita MR and Jorge LV. "Intellectual Capital and Value Creation: Evidence from Portuguese Banking Industry". Electronic Journal of Knowledge Management 4.1 (2005): 11-20.

12. Sampurno H. "Peran Aset Nirwujud pada Kinerja Perusahaan: Studi Pada Industri Farmasi Indonesia". Disertasi Pasca Sarjana Fakultas Ekonomi UI (2005).

13. Santosa B. "Presentation in Journalist Workshop on Water Policy Issues in Indonesia" (2004).

14. Waskitho NT., et al. "Study on Amortization in Irrigation System Management Using Knowledge Management Approach". Paper in ICID Conference Regional Asia ke-6, 10-16 Yogyakarta (2010).

15. Waskitho NT., et al. "Model of Intangible Assets Controlling in Management of Tertiary Irrigation Systems". Jurnal Agritech 32 (2012).

16. Waskitho NT and dan Djudiah. "Controlling Model of Intangible Assets in Secondary Irrigation System Management". Current Agriculture research Journal 4 (2016).

Volume 3 Issue 9 September 2019 (C) All rights are reserved by Nugroho Tri Waskitho., et al. 